\title{
OCULAR MUSCLE PALSY IN DIABETIC PATIENTS
}

\author{
Adel M. Hassan, MD, prof; Hossam T. Al-Sharkawy, MD, ass. \\ Mansoura University, Mansoura Ophthalmic Centre
}

Dysfunction of the ocular motor nerves in patients with microvascular disease is a common cause of acquired diplopia [1]. Most of these cases were attributable to underlying systemic vascular diseases such as diabetes mellitus or hypertension [2]. One report calculated that the incidence of cranial nerve palsy in diabetics was 5 to 10 times higher than in nondiabetics [3]. Because both diabetic ophthalmoplegia and diabetic retinopathy resulted from disturbances of normal microvascular function, it was suggested that the prevalence of each should be directly proportional [2].

A variety of neuro- ophthalmic manifestations have been associated with diabetes. Focal demyelinization of the cranial nerves with subsequent recovery appears to be the mechanism for development of cranial nerve palsies [4]. Diabetes mellitus was considered to be responsible for cranial nerve palsies more than arterial hypertension.

The Purpose of this study is to detect the incidence of extraocular muscle palsy among diabetic patients and also to study the risk factors that may be associated.

MATERIALS AND METHODS.

The study included 932 diabetic patients, whether type 1 (108 patients; $11.59 \%$ ) or type 2 (824 patients; $88.41 \%$ ) diabete mellitus, who attended the diabetes outpatient clinic in Mansoura University, Egypt over two months from 12 January 2012 to 11 March 2012.

They were 253 males $(27.15 \%)$ and 679 females $(72.85 \%)$ and their age ranged from 17 to 85 years with a mean age of $(53.35 \pm 10.26)$ years.

A detailed history and blood laboratory profile were obtained for each patient. Information was collected concerning age, sex, time of onset of diabetes, type of treatment for diabetes (oral hypoglycemic agents or insulin), presence of chronic complications of diabetes, history of other underlying medical conditions especially arterial hypertension and medical history. Ophthalmoscopic examination was done for all patients as well as eyelid movement, ocular motility in all directions of gaze, presence and type of any diplopia and if present, a diplopia chart was mapped and if diabetic retinopathy was diagnosed, it was recorded as non-proliferative or proliferative. Fasting and 2-hour postprandial blood sugar were tested for all patients. Data were expressed as mean \pm standard deviation (SD) and/ or as percentage. Student's t-test was used for statistical evaluation of the data. Statistical significance was posted at level $\mathbf{p}<\mathbf{0 . 0 5}$.

\section{RESULTS}

During the period of the survey a total of 932 diabetic subjects were examined. The mean known duration of diabetes was $(9.61 \pm 7.37)$ years with a range from one month to 40 years. Of these, 348 patients $(37.34 \%)$ were receiving oral hypoglycemic drugs while 584 pa- tients $(62.66 \%)$ were on insulin therapy. Antihypertensive drugs were prescribed for 695 patients $(74.57 \%)$ and the other $237(25.43 \%)$ were not hypertensive.

Fundus examination revealed non-proliferative diabetic retinopathy in 77 patients $(8.26 \%)$ and 55 patients $(5.90 \%)$ had proliferative changes while the other 800 $(85.84 \%)$ had no clinically detectable diabetic retinopathy. Mean fasting blood glucose was $(162.80 \pm 64.01) \mathrm{mg} /$ dl with a range from 46 to $452 \mathrm{mg} / \mathrm{dl}$ while mean 2-hour postprandial blood sugar was $(241.18 \pm 103.23) \mathrm{mg} / \mathrm{dl}$ with a range from 59 to $780 \mathrm{mg} / \mathrm{dl}$.

Facial and ocular muscle palsy was identified in five patients $(0.54 \%)$. Of these five diabetic patients, one $(20 \%)$ was man and four $(80 \%)$ were women; the mean age was $(54.00 \pm 5.43)$ years with a range from 49 to 62 years and the known duration of diabetes was

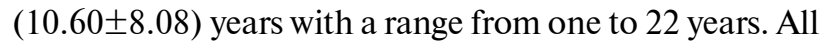
these five patients were of type 2 diabetes mellitus (three of them $(60 \%)$ were on oral antidiabetic treatment and two $(40 \%)$ on insulin therapy). Four of them (80\%) were receiving treatment for arterial hypertension and were controlled while one $(20 \%)$ was not hypertensive. Three patients $(60 \%)$ had non-proliferative diabetic retinopathy while the fundi of the other two (40\%) had no visible diabetic changes. Mean fasting blood glucose was $(214.67 \pm 43.88) \mathrm{mg} / \mathrm{dl}$ with a range from 164 to 240 $\mathrm{mg} / \mathrm{dl}$ while mean 2-hour postprandial blood sugar was $(330.67 \pm 200.05) \mathrm{mg} / \mathrm{dl}$ with a range from 192 to 560 $\mathrm{mg} / \mathrm{dl}$.

The five cases of cranial nerve palsy included two cases (40\%) of facial nerve palsy (fig.1), two cases (40\%) of abducent (VI) nerve palsy (fig.2A\&B) and one case $(20 \%)$ of isolated inferior rectus (partial III nerve) palsy (fig.3A\&B). No fourth nerve palsy was identified in the considered period. The onset of palsy was abrupt in all the cases and all the patients presented with clinical signs of the affected cranial ocular nerves (double vision, loss of or impaired motility of the eyeball, deviation of the eyeball, or inadequate closure of the eyelids).

While these patients were found to have a more poorly controlled diabetes than other none-paretic patients, the differences in the fasting and 2-hour postprandial blood sugar were statistically non-significant. The differences in other risk factors including age, duration of diabetes, type of treatment, associated uncontrolled hypertension and presence and stage of diabetic retinopathy were also not statistically significant.

(C) Adel M. Hassan, Hossam T. Al-Sharkawy, 2012 


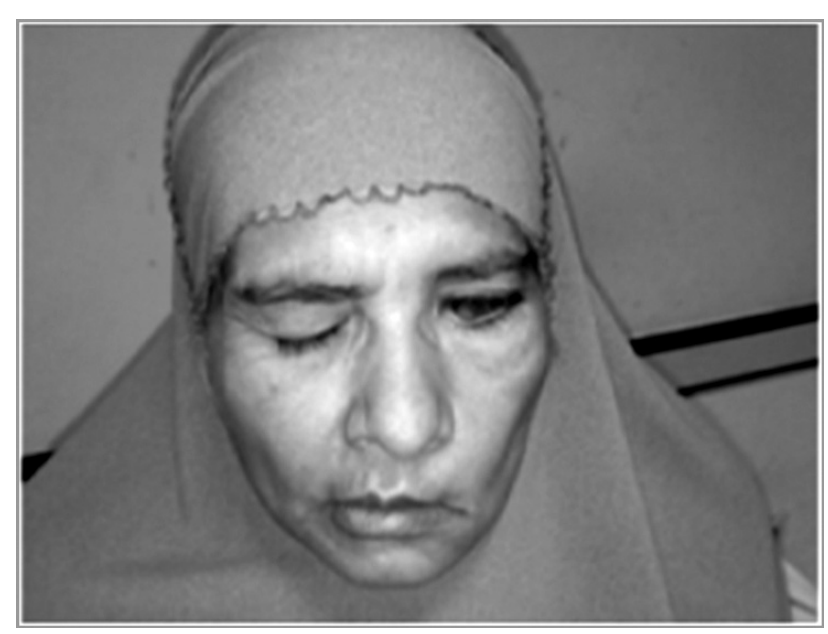

Fig.1; left facial palsy.
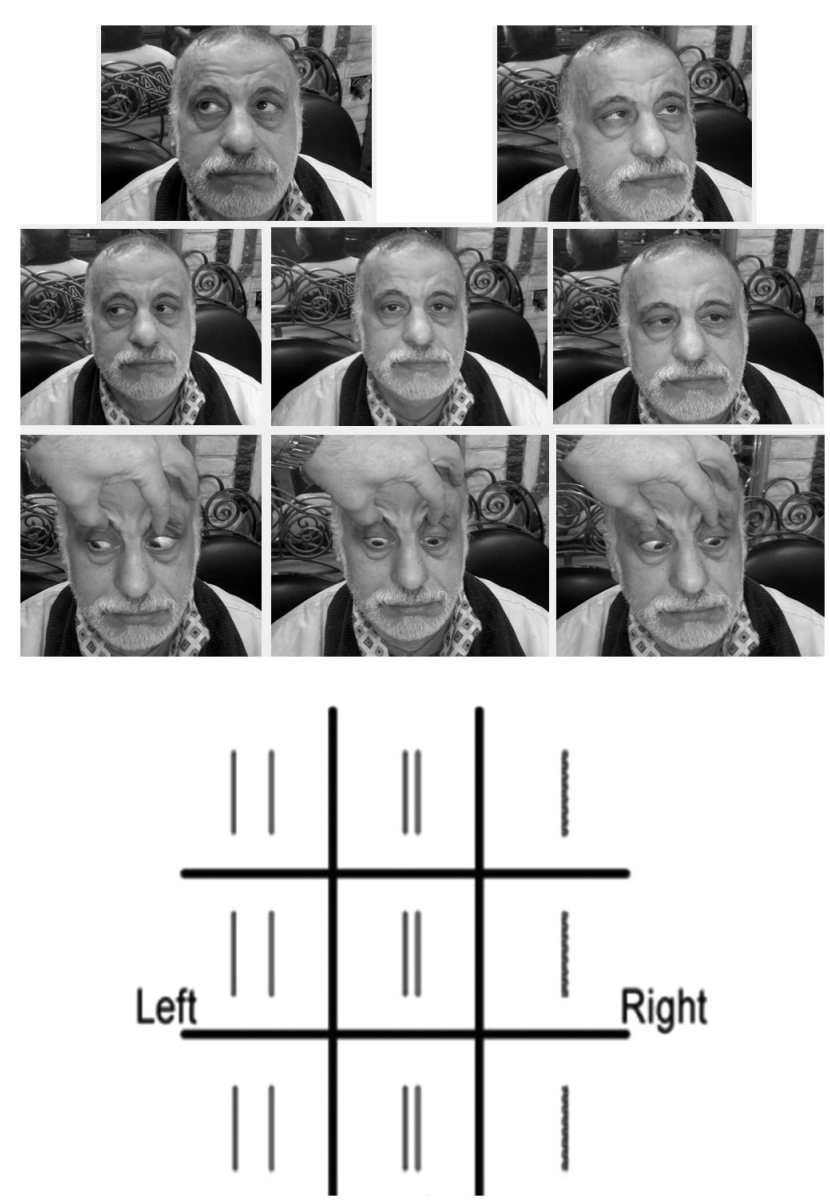

Fig. 2. A - horizontal binocular diplopia when looking to the left due to left lateral rectus palsy, B - diplopia chart.

\section{DISCUSSION}

Diabetic mononeuropathy of the cranial nerves was reported to affect about $1 \%$ of diabetic patients [3] ; ophthalmoplegia, despite being a rare entity in diabetes mellitus, is associated with great anxiety for the patients and often appears to be a serious problem from a diagnostic and therapeutic point of view. Diabetic mononeuropathy should be considered in the presence of signs and symptoms of cranial nerve disturbances in diabetic patients when other causes are excluded [5]. Paralysis of the sixth cranial nerve is recognized as the most common type in most of the series throughout the literature $[6,7,8]$ even though in some series, the third cranial nerve was the most affected $[9,10,11]$.

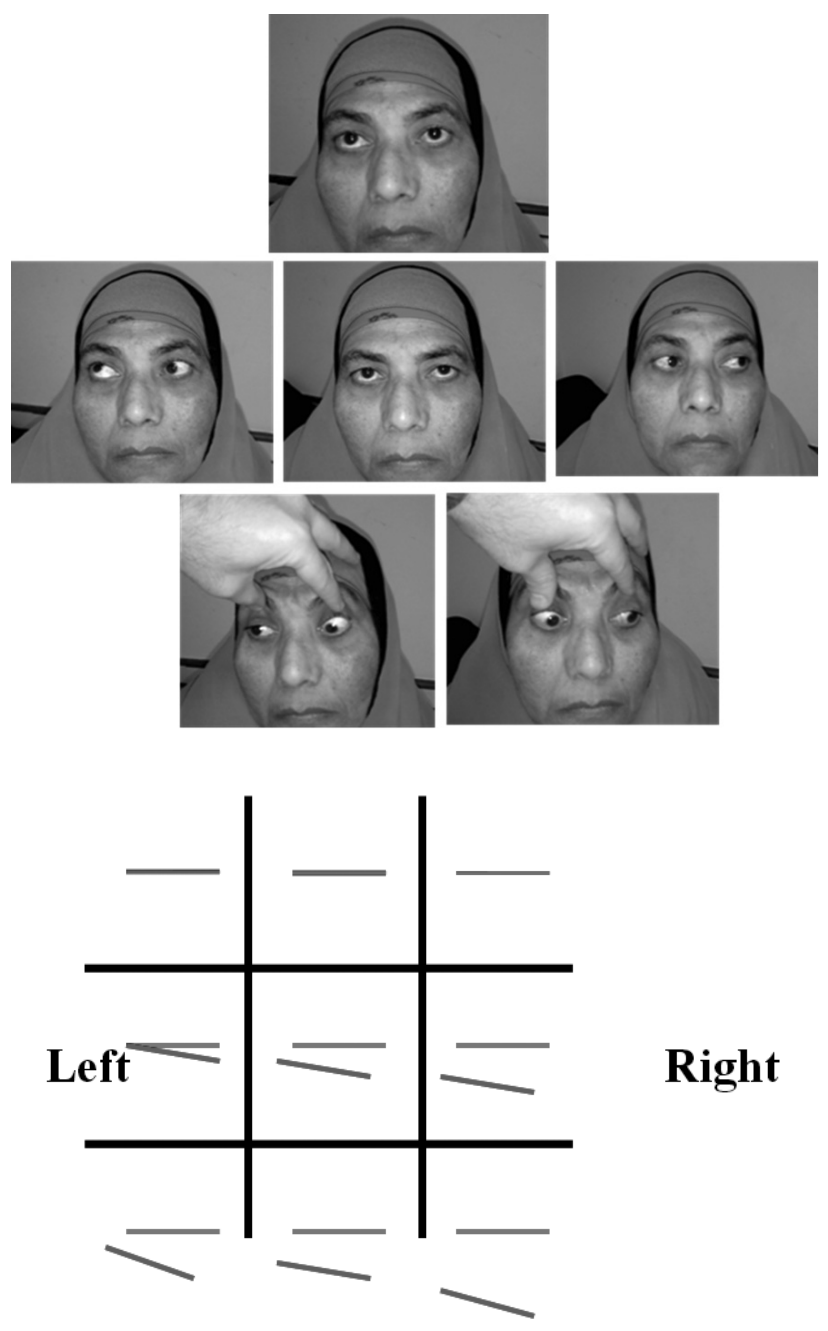

Fig. 3. A - vertical diplopia due to right inferior rectus palsy, B - diplopia chart.

The incidence of ocular muscle palsy among diabetics in the present study was $0.32 \%$, while that of facial palsy was $0.21 \%$. Abducent (VI) nerve involvement $(0.21 \%)$ was more common than that of oculomotor (III) nerve $(0.11 \%)$ while no cases of trochlear (IV) nerve palsy were detected. These results are consistent with previous reports, Funatsu et al. [12], studied the prevalence of diabetic ocular complications and found $0.2 \%$ extraocular muscle palsy in 2,300 cases $(4,600$ eyes) with non-insulin-dependent diabetes mellitus. On the other hand, Watanabe and colleagues [3], studied the incidence of palsy in the third, sixth and seventh cranial nerves among 1961 diabetic patients, where $19(0.97 \%)$ demonstrated cranial nerve palsies. Nine out of these 19 patients showed facial palsy; [6] palsy of the oculomotor nerve; [2] palsy of the abducent nerve; and 3 both ocu- 
lomotor and abducent nerve palsies. The third and sixth cranial nerves are consistently more frequently affected than is the fourth. This phenomenon may not be unique to diabetic ophthalmoplegia. A Mayo Clinic study of over 4000 patients with CN 3, 4, or 6 palsy of any etiology showed the abducens nerve to be most frequently involved (44\%), followed by the oculomotor nerve (28\%), and the trochlear nerve (15\%) [1].

Although the precise etiological role of diabetes in ocular nerve palsy is uncertain, ischemia of the peripheral nerve may be important [13]. Previous reports demonstrated focal ischemic nerve infarction in diabetic oculomotor nerve palsy patients, suggesting that disturbances in microcirculation contribute to the cause of diabetic mononeuropathy [14].

The present study evaluated the risk factors that might contribute to increasing the rate of facial and ocular motor nerve palsy among diabetic patients. Age of the patient, duration of diabetes, type of treatment, associated hypertension, presence and stage of diabetic retinopathy and blood sugar levels all were not relevant in the occurrence of nerve palsy. Jacobson et al. [15], also tried to identify risk factors for ischemic ocular motor nerve palsies and found that hemoglobin Alc levels were significantly higher in diabetic case patients than in diabetic controls, suggesting that relatively poor control may predispose individuals with diabetes to ischemic ophthalmoplegia [16] while Watanabe and colleagues [2], found no differences concerning age, sex, the state of glycemic control, diabetic complications and method of treatment, in the diabetic patients with cranial nerve palsy. They also compared the incidences of diabetic complications between the patients with facial palsy and those with ophthalmoplegia. Only one out of 9 patients with facial palsy $(11 \%)$ had diabetic complications, whereas 7 out of 10 patients with ophthalmoplegia ( $(70 \%)$ demonstrated diabetic complications and the difference was significant. Thus ophthalmoplegia appeared to be more closely related to diabetic metabolism while facial palsy is less strongly correlated with diabetes.

Greco et al. [5], also studied the incidence, the clinical characteristics and risk factors for developing ophthalmoplegia among 6,765 persons with diabetes mellitus and identified ophthalmoplegia in 27 patients $(0.40 \%)$. Isolated III nerve palsies accounted for the majority of patients $(59.3 \%)$, with VI nerve palsies $(29.6 \%)$ occurring more frequently than multiple palsies $(11.1 \%)$. These patients had a marked comorbidity and were found to have a poorly controlled diabetes. The patients with VI nerve palsies showed a tendency toward a higher coexistence of diabetic retinopathy and cardiovascular risk factors than those with III cranial nerve palsies. The fact that the coexistence of diabetic complications and cardiovascular risk factors was slightly higher in patients with VI nerve palsy is compatible with the hypothesis that this ischemic event might be more closely related to diabetes and metabolic syndrome in its pathogenesis.

On the other hand, Trigler and associates [2], who tried to review the clinical characteristics, prevalence, and severity of retinopathy in diabetics with cranial nerve (CN) 3, 4, and/or 6 palsies, concluded that diabetic ophthalmoplegia most commonly involved $\mathrm{CN} 3$ and 6 , with relative sparing of $\mathrm{CN} 4$, multiple cranial nerves were affected simultaneously in $2.6 \%$ of cases, and consecutive palsies occurred in $3.9 \%$ of cases, but they found that type II diabetics with ocular motor $\mathrm{CN}$ palsy had significantly less diabetic retinopathy than do controls. This might imply a different pathophysiologic mechanism for these two microvascular complications of DM. Zorilla and Kozak [17], in a study of 24 patients with diabetic ophthalmoplegia, reported 9 with NPDR (37.5\%) and 2 with PDR (8.3\%) while Dominguez et al. [11], noted no retinopathy in a report of 10 patients with diabetic ophthalmoplegia. In another report of 3 patients with simultaneous, multiple diabetic cranial neuropathies (which may suggest more severe or extensive microvascular compromise), Eshbaugh et al. [18], reported similarly that none had any retinopathy. Acaroglu and co-workers [19], also concluded that the presence and level of diabetic retinopathy were significantly lower in diabetics with cranial nerve palsy than in the age-, sex- and disease-duration-matched controls.

Weber et al. [20], claimed that patients with coexisting vasculopathic risk factors, such as arteriosclerotic disease and hypertension, might be more susceptible to neuropathy versus retinopathy. In the current study, three $(60 \%)$ out of five patients with facial palsy and ophthalmoplegia had non-proliferative diabetic retinopathy and the other two (40\%) had no visible fundus diabetic changes while none of these patients had proliferative diabetic retinopathy. Associated hypertension was found in four $(80 \%)$ of the patients with facial palsy and ophthalmoplegia but all patients proved to have well controlled arterial blood pressure.

The study of Patel and colleagues [21], confirmed the widely accepted belief that diabetes is a risk factor for sixth nerve palsy but, contrary to popular belief, the same study reported that hypertension might not be considered an independent risk factor; however, the combination of diabetes and hypertension was associated with an eightfold increased risk of sixth nerve palsy. This study suggested the possibility that hypertension might worsen the effect of diabetes in ischemic nerve palsies.

The pathogenesis of diabetic cranial neuropathy remained obscured due to paucity of pathological reports. Although there's no unanimity on the direct relationship of vascular lesions with neuropathy, there had been more attention directed to the probable existence of diabetic angiopathy [22]. Dreyfus et al. [22], postulated ischemic neuropathy as the likely pathological change, although no occluded arterioles or venues and no evidence of hemorrhage or inflammation were 
found. In their pathology report, they remarked that only one-fourth to one-fifth of the nerve fibers disappeared microscopically, yet almost all of the function of the oculomotor nerve had been affected. Combing with clinical self recovery trait, a functional rather than an irreversible structural change was proposed. Asbury et al. [14 dentified hyalinization of the intra-neural arterioles (30-80 $\mu \mathrm{m})$ with endothelial proliferative degeneration and resultant stenosis in the lesioned nerves that provided additional support of ischemic pathology. Focal non-inflammatory demyelination in the intracavernous portion of third cranial nerve was also observed in autopsy [23]. This may provide explanation of pupillary sparing as the oculomotor parasympathetic fibers are small myelinated or unmyelinated [22].

Management is expectant with strong reassurance to the patient for recovery. Maintaining optimal glycemic control as well as minimizing the other stronger risk factors for ischemia, including hypertension and hyperlipidemia, may aid recovery. Most of these patients can be observed with sequential examinations; nevertheless, if new neurologic signs or symptoms appear, or the nerve palsy progresses, repeat neurologic evaluation with neuroimaging is warranted [5].

In conclusion, diabetic cranial neuropathies is one of the neurological complications among diabetic patients. Facial and extraocular muscle palsy in diabetic patients has no relation to the presence or severity of diabetic retinopathy. No risk factors could be detected in the affected patient such as age, duration of diabetes, blood sugar level, type of antidiabetic treatment, arterial hypertension nor associated arteriolosclerosis. In the diabetic cranial neuropathy, the prognosis is relatively benign and spontaneous recovery is expected within three months in most patients.

\section{REFERENCES}

1. Richards B. W., Jones F. R., Younge B. R. (1992) Causes and prognosis in 4278 cases of paralysis of the oculomotor, trochlear and abducens cranial nerves // Am J Ophthalmol. - V.113. - P.489-496

2. Trigler L., Siatkowski R. M., Oster A. S. et al. (2003) Retinopathy in patients with diabetic ophthalmoplegia // Ophthalmology. - Aug; 110 (8). - P.1545-50

3. Watanabe K., Hagura R., Akanuma Y. et al. (1990) Characteristics of cranial nerve palsies in diabetic patients // Diabetes Res Clin Pract. - № 10. - P.19-27

4. Mahoney B. P. (1994) Diabetes in Blaustein BH (ed): Ocular manifestations of systemic disease. New York, Churchil Livingstone 9. - P.149-163

5. Greco D., Gambina F., Maggio F. (2009) Ophthalmoplegia in diabetes mellitus: a retrospective study // Acta Diabetol. - Mar; 46(1). - P.23-6.
6. Rush J. A., Younge B. R. (1981) Paralysis of cranial nerves III, IV and VI: cause and prognosis in 1000 cases // Arch Ophthalmol. - 99. - P.76-79

7. Lazzaroni F., Laffi G. L., Galuppi V., Scorolli L. (1993) Paralysis of oculomotor nerves in diabetes mellitus. A retrospective study of 44 cases // Rev Neurol Paris. - V.149. P.571-573

8. Tiffin P. A., MacEwen C. J., Craig E. A., Clayton G. (1996) Acquired palsy of the oculomotor, trochlear and abducens nerves // Eye. - 10. - P.377-384

9. Berlit P. (1991) Isolated and combined pareses of cranial nerves III, IV, and VI. A retrospective study of 412 patients // J Neurol Sci. - 103. - P.10-15

10. Batocchi A. P., Evoli A., Majolini L. et al. (1997) Ocular palsies in the absence of other neurological or ocular symptoms: analysis of 105 cases // J Neurol. - V.244. P.639-645.

11. Dominguez D., Gomensoro J., Temesio P., Rodriguez-Barrios R. (1974) Diabetic ophthalmoplegia // Acta Diabet Lat. - 11. - P.198-205.

12. Funatsu H., Suto C., Hori S.et al. (1993) Prevalence of diabetic ocular complications and systemic factors // Nihon Ganka Gakkai Zasshi. - Aug; 97 (8). - P.947-54

13. Smith B. E., Dyck P. J. (1992) Subclinical histopathological changes in the oculomotor nerve in diabetes mellitus // Ann Neurol. - V.32. - P.376-385

14. Asbury A. K., Aldredge H., Hershberg R., Fisher C. M. (1970) Oculomotor palsy in diabetes mellitus: a clinicopathological study // Brain. - V.93. - P.955-966.

15. Jacobson D. M., McCanna T. D., Layde P. M. (1994) Risk factors for ischemic ocular motor nerve palsies // Arch Ophthalmol. - V.112. - P.961-966

16. Koenig R. J., Peterson C. M., Jones R. L. et al. (1976) correlation of glucose regulation and hemoglobin A1c in diabetes mellitus // N Engl J Med. - V.295. - P.417-420.

17. Zorrilla E., Kozak G. P. (1967) Ophthalmoplegia in diabetes mellitus // Ann Intern Med. - V.67. - P.968-976.

18. Eshbaugh C. G., Siatkowski R., Smith J. L., Kline L. B. (1995) Simultaneous, multiple cranial neuropathies in diabetes mellitus // J Neuroophthalmol. - V.15. - P.219-224

19. Acaroglu G., Akinci A., Zilelioglu O. (2008) Retinopathy in patients with diabetic ophthalmoplegia // Ophthalmologica. - V.222(4). - P.225-8

20. Weber R. B., Daroff R. B., Mackey E. A. (1970) Pathology of oculomotor nerve palsy in diabetics // Neurology. V.20. - P.835-8

21. Patel S. V., Holmes J. M., Hodge D. O., Burke J. P. (2005) Diabetes and hypertension in isolated sixth nerve palsy // Ophthalmology. - V.112. - P.760-763.

22. Dreyfus P. M., Hakim S., Adams R. D. (1957) Diabetic ophthalmoplegia. Report of case, with postmortem study and comments on vascular supply of human oculomotor nerve // Arch Neurol Psychiatry. - V.77. - P.337-349

23. Tu M. C., Chang Y. Y., Lin T .K. (2010) Recurrent multiple cranial neuropathies in a diabetic patient // Acta Neurol Taiwan. - V.19. - P.208-212

Поступила 08.05.2012. 


\title{
ПАРАЛИЧ ГЛАЗНЫХ МЫШЦ У ПАЦИЕНТОВ С ДИАБЕТОМ
}

Adel M. Hassan,MD, prof; Hossam T. Al-Sharkawy,MD, ass.

\section{Мансура, Египет}

$C$ целью определения частоты паралича лицевых и экстраокулярных мышц среди больных диабетом проведено обследование 932 пациентов с инсулин-зависимым и инсулин-независимым диабетом.

У всех пациентов проведено изучение состояния глазного дна, степени закрытия век, функции наружных глазных мышц, а также наличия и типа диплопии. Кроме того, определяли уровень сахара в крови, общее артериальное давление и степень артериосклероза.

Паралич лицевого нерва выявлен у двух больных, паралич наружной прямой и нижней прямой мышц у одного пациента.

Сделан вывод о том, что паралич экстраокулярных мышц не зависит от степени диабетической ретинопатии. Артериальная гипертензия, атеросклероз также не являются факторами риска. Выявленные случаи паралича были транзиторными и исчезли спустя несколько месяцев.

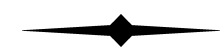

УДК 617.735-002-02:616.379-008.64+616.153.915-39]+615.356

\section{ВЛИЯНИЕ ВИТАМИНА В У БОЛЬНЫХ ДИАБЕТИЧЕСКОЙ РЕТИНОПАТИЕЙ}

\author{
К. П. Павлюченко, д. мед. Н., проф., С. Ю. Могилевский, д. мед. Н., проф.,
}

\section{А. Л. Чуйко, врач}

Донецкий национальный медицинский университет им. М. Горького, Украинский государственный научно-исследовательский институт медико-социальных проблем инвалидности МОЗ Украины

\begin{abstract}
В роботі наводяться результати дослідження продуктів перекисного окислення ліпідів і оксоальдегідів в крові хворих на діабетичну ретинопатію і вплив на них профілактичного лікування з включенням препаратів вітаміну В6. Під нашим спостереженням перебувало 117 хворих з иукровим діабетом II типу, що склали 2 групи спостереження. Пацієнти першої групи отримували загальноприйняте профілактичне лікування з включенням препаратів вітаміну $B_{6}-$ «Кардонату» всередину $i$ «іридоксину гідрохлорид» внутрішньом'язово. Друга група отримувала комплекс традиційного лікування: дієта, фітотерапія, засоби, що поліпшують мікроциркуляцію, ангіопротектори. Було встановлено, що у хворих на иукровий діабет та непроліферативну діабетичну ретинопатію є достовірне підвищення рівня метилгліоксалю, дієнових кон'югатів і малонового діальдегіду. Загальноприйняте профілактичне лікування дозволило знизити рівень метилгліоксалю на 11,7 \%, дієнових кон'югатів на 14,1\%, малонового діальдегіду на 20,2\%. Профілактичне лікування з включенням препаратів вітаміну $B_{6}$ дозволило знизити рівень цих показників на 16,5\% і 24,5\% відповідно.
\end{abstract}

Ключевые слова: диабетическая ретинопатия, профилактическое лечение, витамин В6

Ключові слова: діабетична ретинопатія, профілактичне лікування, вітамін В6

Введение. Проблема сахарного диабета (СД) в настоящее время становится все более и более значимой. Сахарным диабетом страдает до $5 \%$ населения земного шара, затрагивая людей всех возрастов. Ежегодно этот процент увеличивается [15, 19, 29]. Поражение сетчатки развивается практически у 90 \% больных в различные сроки после возникновения СД и служит причиной снижения и потери зрительных функций $[1,6]$.

Диабетическая ретинопатия (ДР) является основной причиной слепоты среди людей в возрасте от 20 до 64 лет. Это связано, в первую очередь, с недостаточным знанием патогенеза заболевания при разных формах СД и стадиях ДР, и в связи с этим, недостаточно эффективным и обоснованным лечением [2, 3, 22]. На сегодняшний день при развитии ДР терапевтические возможности остаются весьма ограниченными. Большинство консервативных методик лечения ДР направлено на устранение патологических изменений гемомикроциркуляции и ограничение зон ишемии в сетчатке, при этом не учитывается изменение метаболических и

(c) К. П. Павлюченко, С. Ю. Могилевский, А. Л. Чуйко, 2012 